\title{
Preferential Targeting of Lateral Entorhinal Inputs onto Newly Integrated Granule Cells
}

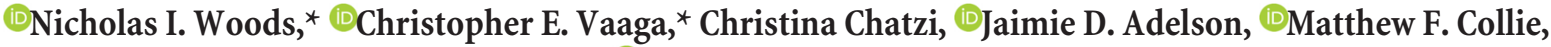 \\ Julia V. Perederiy, Kenneth R. Tovar, and @Gary L. Westbrook \\ Vollum Institute, Oregon Health and Science University, Portland, Oregon 97239
}

\begin{abstract}
Mature dentate granule cells in the hippocampus receive input from the entorhinal cortex via the perforant path in precisely arranged lamina, with medial entorhinal axons innervating the middle molecular layer and lateral entorhinal cortex axons innervating the outer molecular layer. Although vastly outnumbered by mature granule cells, adult-generated newborn granule cells play a unique role in hippocampal function, which has largely been attributed to their enhanced excitability and plasticity (Schmidt-Hieber et al., 2004; Ge et al., 2007). Inputs from the medial and lateral entorhinal cortex carry different informational content. Thus, the distribution of inputs onto newly integrated granule cells will affect their function in the circuit. Using retroviral labeling in combination with selective optogenetic activation of medial or lateral entorhinal inputs, we examined the functional innervation and synaptic maturation of newly generated dentate granule cells in the mouse hippocampus. Our results indicate that lateral entorhinal inputs provide the majority of functional innervation of newly integrated granule cells at $21 \mathrm{~d}$ postmitosis. Despite preferential functional targeting, the dendritic spine density of immature granule cells was similar in the outer and middle molecular layers, which we speculate could reflect an unequal distribution of shaft synapses. However, chronic blockade of neurotransmitter release of medial entorhinal axons with tetanus toxin disrupted normal synapse development of both medial and lateral entorhinal inputs. Our results support a role for preferential lateral perforant path input onto newly generated neurons in mediating pattern separation, but also indicate that medial perforant path input is necessary for normal synaptic development.
\end{abstract}

Key words: dentate gyrus; neurogenesis; pattern separation; retroviral labeling; synapse formation; tetanus toxin

\section{Significance Statement}

The formation of episodic memories involves the integration of contextual and spatial information. Newly integrated neurons in the dentate gyrus of the hippocampus play a critical role in this process, despite constituting only a minor fraction of the total number of granule cells. Here we demonstrate that these neurons preferentially receive information thought to convey the context of an experience. Each newly integrated granule cell plays this unique role for $\sim 1$ month before reaching maturity.

\section{Introduction}

As the entry point to the trisynaptic hippocampal circuit, the dentate gyrus has several interesting features, including a "sparse" network design (Boss et al., 1985; Rolls et al., 1998), laminated inputs carrying distinct informational content (Witter, 2007; Knierim et

Received June 21, 2017; revised April 26, 2018; accepted May 17, 2018.

Author contributions: N.I.W. and G.L.W. designed research; N.I.W., C.E.V., C.C., J.D.A., M.F.C., J.V.P., and K.R.T. performed research; N.I.W., C.E.V., C.C., J.D.A., M.F.C., J.V.P., and K.R.T. analyzed data; N.I.W., C.E.V., and G.L.W. wrote the paper.

This work was supported by National Institutes of Health Grants R01 NS080979 and P30 NS061800 and by the Ellison Medical Foundation (G.L.W.). We thank Stefanie Kaech Petrie for help with imaging, Eric Schnell for guidance with electrophysiology, and Sue Aicher for assistance with electron microscopy.

*N.I.W and C.E.V. contributed equally to this work.

The authors declare no competing financial interests.

Correspondence should be addressed to Gary L. Westbrook, Vollum Institute, L474, Oregon Health and Science University, 3181 SW Sam Jackson Park Road, Portland OR, 97008. E-mail: westbroo@ohsu.edu.

N.I. Woods' present address: Medical Scientist Training Program, University of California San Francisco, San Francisco, CA 94143.

DOI:10.1523/JNEUROSCI.1737-17.2018

Copyright $\odot 2018$ the authors $\quad 0270-6474 / 18 / 385843-11 \$ 15.00 / 0$ al., 2014), and the participation of mature granule cells alongside the continuous integration of newly generated neurons (OverstreetWadiche and Westbrook, 2006; Ming and Song, 2011). Hippocampal granule cells receive highly laminar inputs from the entorhinal cortex within the molecular layer of the dentate gyrus. Input from the medial entorhinal cortex, conveying spatial cues, is restricted to the middle molecular layer (MML; Ferbinteanu et al., 1999; Hafting et al., 2005; Hargreaves et al., 2005; Yasuda and Mayford, 2006; Witter, 2007; Van Cauter et al., 2013), whereas input from the lateral entorhinal cortex conveying contextual information is restricted to the outer molecular layer (OML; Hargreaves et al., 2005; Hunsaker et al., 2007; Witter, 2007; Deshmukh and Knierim, 2011; Yoganarasimha et al., 2011; Tsao et al., 2013). Despite being substantially outnumbered by mature granule cells, newly integrated granule cells are thought to uniquely contribute to pattern separation (Clelland et al., 2009; Sahay et al., 2011; Nakashiba et al., 2012; Tronel et al., 2012). That is, they foster the ability to distinguish between subtly different contexts, one of the primary functions of the dentate gyrus (Deng et al., 2010; Aimone et al., 
2011). This unique function must occur during a narrow time window between initial integration into the perforant path circuit ( $\sim 3$ weeks postmitosis) and the complete maturation of synapses ( $>8$ weeks postmitosis; van Praag et al., 2002; Ambrogini et al., 2004; Overstreet et al., 2004; Laplagne et al., 2006; OverstreetWadiche et al., 2006; Zhao et al., 2006; Kumamoto et al., 2012; Brunner et al., 2014).

The search for unique functions of newly integrated neurons has largely focused on intrinsic properties, such as enhanced excitability and plasticity (Schmidt-Hieber et al., 2004; Abrous et al., 2005; Ge et al., 2007; Marín-Burgin et al., 2012; Dieni et al., 2013). However, newborn neurons also undergo rapid changes in connectivity in the first few weeks after mitosis. This process likely differs from synapse remodeling in early development (Goodman and Shatz, 1993; Katz and Shatz, 1996; Walsh and Lichtman, 2003), as newborn neurons integrate into an already established circuit (Toni et al., 2007, 2008) and compete for synaptic innervation with pre-existing axons of the perforant path. Rabies-based circuit mapping also suggests that inputs to newly integrated neurons may differ from mature granule cells (Vivar et al., 2012).

Here, using retroviral labeling of newborn neurons and laminarspecific optogenetic stimulation of entorhinal inputs, we directly assayed functional synaptic integration of newborn granule cells over the course of excitatory synapse development. Our results indicate that newly integrated granule cells preferentially receive functional synaptic input from the lateral entorhinal cortex, whereas mature granule cells receive balanced input from the medial and lateral entorhinal cortex. Although medial perforant path (MPP) input was weak in newly integrated granule cells, chronic silencing of this pathway using tetanus toxin impaired the functional and morphological development of lateral perforant path (LPP) inputs.

\section{Materials and Methods}

Animals. We used male and female C57BL/6 mice. Animal procedures were performed in accordance with the Oregon Health and Science University Institutional Animal Care and Use Committee, Biosafety Committee protocols, and National Institutes of Health guidelines for the safe handling of animals.

Viral constructs. To selectively transfect and visualize adult-born hippocampal granule cells, we used a replication-deficient Moloney murine leukemia virus-based retroviral vector that requires cell mitosis for transduction (Luikart et al., 2011). The retrovirus contained an internal ubiquitin 6 promoter that drives expression of GFP (viral titer $10^{5}$ ) as described previously (pRubi-GFP; Luikart et al., 2011). To express the light-activated ion channel channelrhodopsin-2 (ChR2) selectively in entorhinal cortex axons projecting to the MML or OML, we stereotaxically injected an AAV9-CAG-ChR2-eGFP viral construct (University of North Carolina Viral Core) into the medial or lateral entorhinal cortex. Laminar-specific labeling was confirmed by examination of GFP fluorescence in the entorhinal cortex and in the dentate molecular layer. Injections affecting both the lateral and medial entorhinal cortex were excluded from the analysis. To selectively silence axons, we made a custom tetanus neurotoxin (TeNT) virus (AAV9-CAG-TeNT-mCherry, viral titer $10^{13}$ ) by cloning a $2 \mathrm{~kb}$ fragment encoding the light chain of tetanus toxin fused with mCherry into an AAV backbone using InFusion cloning. AAV vectors were serotyped with AAV9 coat proteins and packaged at the University of North Carolina Vector Core.

Stereotaxic injections. Stereotaxic viral injections into 6-8-week-old male and female C57BL/6 mice were performed using a Model 1900 Stereotaxic Alignment System (David Kopf Instruments). Mice were anesthetized with $2 \%$ isoflurane, and a small incision was created over the skull following application of artificial tears to the eyes and antibiotic/ iodine around the incision site. A Model 1911 Stereotaxic Drill (David Kopf Instruments) was used to create burr holes over the injection site. pRubi-GFP retrovirus to label mitotically active granule cells was injected into the dentate gyrus (coordinates, from bregma: anteroposterior, -1.9 $\mathrm{mm}$; lateromedial: $\pm 1.1 \mathrm{~mm}$; dorsoventral, $-2.5 \mathrm{~mm},-2.3 \mathrm{~mm}$ ). One microliter of nondiluted virus was injected at $250 \mathrm{nl} / \mathrm{min}$ with a $10 \mu \mathrm{l}$ Hamilton syringe fitted with a 30 gauge needle using a Quintessential stereotaxic injector (Stoetling). After each injection, the needle was left in place for $1 \mathrm{~min}$ to allow for diffusion of the virus and prevent backflow. Injections of AAV9-CAG-CHR2-GFP into the lateral entorhinal cortex were made at the following coordinates: anteroposterior (from bregma), $-3.4 \mathrm{~mm}$; lateromedial (from bregma), $\pm 4.0 \mathrm{~mm}$; dorsoventral (from brain surface), $-2.4 \mathrm{~mm}$. Injections of AAV9-CAG-ChR2-GFP or AAV9CAG-TeNT-mCherry into the medial entorhinal cortex were made at the following coordinates: anteroposterior (from bregma), $-4.5 \mathrm{~mm}$; lateromedial (from bregma), $\pm 3.0 \mathrm{~mm}$; dorsoventral (from brain surface), $-3.2 \mathrm{~mm}$. To control for differences in the degree of innervation from the medial and lateral entorhinal cortex (Dolorfo and Amaral, 1998; Ohara et al., 2013), injections in the dentate gyrus were targeted to the intermediate region across the septotemporal axis (van Groen et al., 2003; Strange et al., 2014), which receives approximately equal innervation from the medial and lateral entorhinal cortex. Where appropriate, pRubi and ChR2 were injected during the same surgery. Following injection, mice received topical lidocaine and drinking water with cherryflavored Tylenol, and were monitored every $24 \mathrm{~h}$ for $3 \mathrm{~d}$.

Immunohistochemistry and spine counts. Transcardiac perfusion of deeply anesthetized mice [2\% 2,2,2-tribromoethanol $(0.7-0.8 \mathrm{ml})]$ was performed with ice-cold $4 \%$ sucrose in $0.1 \mathrm{~m}$ PBS followed by fixative containing $4 \%$ sucrose and $4 \%$ paraformaldehyde (PFA) in PBS. Brains were removed and postfixed ( $4 \% \mathrm{PFA}, 1 \times \mathrm{PBS})$ overnight at $4^{\circ} \mathrm{C}$. The hippocampus was sectioned (coronal, $100 \mu \mathrm{m}$ ) using a Leica VT 1000S vibratome. Sections were permeabilized with $0.4 \%$ Triton X-100 in PBS (PBS-T), blocked with filtered $10 \%$ horse serum in PBS-T and incubated in primary antibody overnight in $1.5 \%$ horse serum in PBS-T. Primary antibodies included the following: 1:300 Alexa Fluor 488-conjugated rabbit anti-GFP (catalog \#A21311, Invitrogen), 1:500 anti-VGlut2 (catalog \#135 404, Synaptic Systems), and 1:500 anti-glial-associated fibrillary protein (GFAP; catalog \#Z-0334, DAKO). Sections were then rinsed with PBS-T and incubated for 2-3 h at room temperature in PBS-T with the following secondary antibodies: 1:300 Alexa Fluor 488-conjugated anti-GFP (A21311, Invitrogen), 1:200 goat anti-guinea pig Alexa Fluor 568 (A11075, Invitrogen), and 1:200 goat anti-rabbit Alexa Fluor 488 (A11034, Invitrogen). The mCherry-TeNT signal was extremely bright and was visualized without use of secondary enhancement with antibodies. The tissue was counterstained with DAPI using Fluoromount G with DAPI (SouthernBiotech). All antibodies have been well characterized in prior studies in our laboratory, and staining was not observed when the primary antibody was omitted.

Images were acquired using either a Zeiss LSM 770 or LSM 780 laserscanning confocal microscope on a motorized AxioObserver $\mathrm{Z} 1$ inverted scope (Carl Zeiss MicroImaging). Dendrites for spine analysis were imaged using a $63 \times$ objective (1.4 numerical aperture, oil, $2 \times$ zoom). For each imaged cell, dendritic segments in the MML and the OML were imaged. The MML and OML were distinguished based on VGluT2 immunofluorescence pattern, which begins at the border between the inner molecular layer and the MML. MML dendritic segments were therefore imaged at the beginning of the VGluT2 staining nearest the granule cell body layer, whereas OML dendritic segments were imaged at the distal tip of the molecular layer. Spine density analysis was performed blinded to experimental condition. The Cell Counter plugin in FIJI (National Institutes of Health) was used to count and categorize spines (Harris et al., 1992), and Simple Neurite Tracer (FIJI) was used to measure dendritic segment length. Spine density and spine type between the MML and OML was compared across conditions (control and TeNT overexpression) and developmental time points (3-12 weeks after viral injection). Spine morphology was classified into two groups: mushroom spines, containing a spine head $(2 \times$ shaft diameter $)$ or filopodia-like for protrusions lacking a spine head.

Electrophysiology. Electrophysiological recordings were made $21 \mathrm{~d}$ after viral injection into the entorhinal cortex to allow for construct expression. Acute brain slices were prepared as described previously (Perederiy et al., 2013). Briefly, animals were anesthetized with an intraperitoneal 
injection of 2\% 2,2,2-tribromoethanol (0.7-0.8 ml), and perfused with an ice-cold, oxygenated modified ACSF, which contained the following (in mM): 110 choline- $\mathrm{Cl}, 7 \mathrm{MgCl}_{2}, 2.5 \mathrm{KCl}, 1.25 \mathrm{NaH}_{2} \mathrm{PO}_{4}, 0.5 \mathrm{CaCl}, 1.3$ $\mathrm{Na}$-ascorbate, and $25 \mathrm{NaHCO}_{3}$. Hippocampi were resected and cut at $300 \mu \mathrm{m}$ transverse to the longitudinal axis of the hippocampus on a Leica 1200 S vibratome. Slices from the intermediate region (Strange et al., 2014) were used for these studies. Slices were allowed to incubate for $1 \mathrm{~h}$ in $37^{\circ} \mathrm{C}$ normal ACSF, which contained the following (in $\mathrm{mM}$ ): $125 \mathrm{NaCl}, 2.5 \mathrm{KCl}$, 2.0 CaCl, $1.0 \mathrm{MgCl}_{2}, 1.25 \mathrm{NaH}_{2} \mathrm{PO}_{4}, 25 \mathrm{NaHCO}_{3}$, and 25 glucose.

For extracellular field recording, we used glass pipettes $(2-3 \mathrm{M} \Omega$ ) filled with normal ACSF placed into the lamina of interest. Presynaptic fibers were stimulated using either a bipolar electrode (3-7 V, $0.5 \mathrm{~V}$ steps) or optogenetic stimulation ( $1 \mathrm{~ms}$ pulses of $470 \mathrm{~nm}$ blue light). Whole-cell voltage-clamp recordings were made using glass pipettes (5-8 $\mathrm{M} \Omega$ ). Mature granule cells were selected based on input resistance $<750 \mathrm{M} \Omega$ $(495 \pm 37 \mathrm{M} \Omega)$ and soma position in the outer one-third of the granule cell layer (Ambrogini et al., 2004; Overstreet-Wadiche and Westbrook, 2006). The whole-cell recording solution contained the following (in mM): 100 gluconic acid, 0.2 EGTA, 5 HEPES, 2 Mg-ATP, 0.3 Li-GTP, pH $7.2,295 \mathrm{mOsm}$, adjusted with $50 \% \mathrm{CsOH}$ such that final concentration of Cs-gluconate was 100-120 mM. The liquid junction potential $(-7 \mathrm{mV})$ was not corrected. Series resistance of the cell was continually monitored with a $10 \mathrm{mV}$ hyperpolarizing step, and cells with input resistance $>25 \mathrm{M} \Omega$ at any point were excluded from analysis. Data were acquired at $10 \mathrm{kHz}$ and Bessel filtered at $4 \mathrm{kHz}$ on a Multiclamp 700B (Molecular Devices) and recorded using AxoGraphX acquisition software (www.axograph.com).

Optogenetic stimulation was provided by a $470 \mathrm{~nm}$ LED (ThorLabs). Light pulses (1 ms) were delivered through the microscope objective, which was centered over the appropriate lamina. Optical stimulation was delivered over a range of intensities until a maximal response was elicited, which was then used for the remainder of the experiment. Optically evoked EPSCs were collected from mature and newly integrated cells in the same cohort of animals. Peak EPSC amplitudes were measured using a built-in routine in AxographX. Miniature EPSCs (mEPSCs) were recorded in the presence of SR95531 $(10 \mu \mathrm{M})$ and TTX $(1 \mu \mathrm{M})$ to isolate miniature excitatory events. Quantal events were detected using a sliding window template consisting of a single exponential ( $-10 \mathrm{pA}, 1 \mathrm{~ms}$ rise time, $6 \mathrm{~ms}$ decay time constant). Individual events were then manually inspected. mEPSC analysis was performed with the experimenter blinded to condition.

Cell culture. Mouse hippocampal neurons were cultured on glial microislands as described previously (Tovar et al., 2009). Briefly, neonatal (postnatal day 0-1) male mice were decapitated, and the hippocampi were dissected. Microislands were generated by plating at 125,000 cells/35 mm dish. After $7 \mathrm{~d}$ in vitro, cultures were treated with $200 \mu \mathrm{M}$ glutamate for $30 \mathrm{~min}$ to kill any neurons. Neurons were then plated on the remaining glial feeder layer at 25,000 cells/35 mm dish and maintained in a tissue culture incubator $\left(37^{\circ} \mathrm{C}, 5 \% \mathrm{CO}_{2}\right)$ until use. The culture medium consisted of minimum essential media with $2 \mathrm{~mm}$ glutaMAX (Invitrogen), 5\% heat-inactivated fetal calf serum (Lonza), and $1 \mathrm{ml} / \mathrm{L}$ MITO+ Serum Extender (BD Biosciences). The culture medium was supplemented with glucose to a final concentration of $21 \mathrm{~mm}$. For validation of tetanus toxin constructs, cultured neurons were transduced at $1 \mathrm{~d}$ in vitro by replacing $50 \%$ of the culture medium with virus-containing medium ( 1 $\mu \mathrm{l}$ of virus in $500 \mu \mathrm{l}$ of medium). After $24 \mathrm{~h}$, the virus-containing medium was removed and replaced with fresh complete medium.

Whole-cell voltage-clamp recordings were made from cultured neurons 3-16 d in vitro. The extracellular recording solution consisted of the following (in mM): $158 \mathrm{NaCl}, 2.4 \mathrm{KCl}, 1.3 \mathrm{CaCl}_{2}, 1 \mathrm{MgCl}_{2}, 10 \mathrm{HEPES}$, and 10 D-glucose, $\mathrm{pH} 7.4,320 \mathrm{mOsmol}$. Glass pipettes $(2-6 \mathrm{M} \Omega$ ) were filled with a solution which contained the following (in $\mathrm{mM}$ ): $140 \mathrm{~K}$-gluconate, $4 \mathrm{CaCl}_{2}, 8 \mathrm{NaCl}, 2 \mathrm{MgCl}_{2}, 10$ EGTA, 10 HEPES, $4 \mathrm{Na}_{2} \mathrm{ATP}$, and 0.2 $\mathrm{Na}_{2} \mathrm{GTP}, \mathrm{pH} 7.4,319$ mOsmol. Autaptic EPSCs were elicited from neurons in isolation on a glial microisland with a brief voltage command $(+30 \mathrm{mV}, 0.5 \mathrm{~ms})$ to elicit an unclamped action potential. Recordings were made in the presence of $10 \mu \mathrm{M}$ SR95531 and $10 \mu \mathrm{M}(\mathrm{R})$-CPP [(R)3-(2-carboxypiperazin-4-yl)propyl-1phosphonic acid] to block $\mathrm{GABA}_{\mathrm{A}}$ and NMDA receptors, respectively. Data were acquired using an Axopatch 1C amplifier and AxographX (www.axograph.com) acquisition software. In all recordings, the series resistance was $<10 \mathrm{M} \Omega$ and was continuously monitored with a $-10 \mathrm{mV}$ step. Data were low-pass Bessel filtered at $4 \mathrm{kHz}$ and sampled at $10 \mathrm{kHz}$.

Electron microscopy. Ultrastructural analysis of control and TeNTexpressing MPP axons were conducted $21 \mathrm{~d}$ after viral injection, as in Perederiy et al., 2013. Two control (pRubi-expressing) and two pRubiexpressing and TeNT-expressing animals were perfused with PBS followed by a $3.75 \%$ acrolein and 2\% PFA fixative. The brains were then extracted and stored in $2 \%$ PFA for $\geq 1 \mathrm{~h}$ before sectioning at $40 \mu \mathrm{m}$ in the coronal plane using a Leica VT 1000 S vibratome (Leica Microsystems). Sections including the dorsal hippocampus were incubated in $1 \%$ sodium borohydride for $30 \mathrm{~min}$ to reduce nonspecific binding, followed by incubation in $10 \%$ Triton-X for 45 min to increase antibody penetration. Next, sections were blocked with $0.5 \%$ bovine serum albumin for $1 \mathrm{~h}$ followed by primary antibody incubation directed against pRubi-GFP (rabbit $\alpha$-GFP, 1:500; Millipore, catalog \#AB3080) or TeNT-mCherry (Mouse $\alpha$-mCherry, 1-500; Living Colors, catalog \#632543) overnight at $4^{\circ} \mathrm{C}$. Following primary antibody incubation, the tissue was thoroughly washed with $0.4 \%$ Triton-X. To visualize GFP, tissue was incubated in biotinylated goat $\alpha$-rabbit secondary antibody (1:200; Vector Laboratories, catalog \#BA-1000) for $2 \mathrm{~h}$ at room temperature followed by avidin-binding complex (Vector Laboratories) for 30 min then reacted with $\mathrm{DAB}-\mathrm{H}_{2} \mathrm{O}_{2}$ solution for $5.5 \mathrm{~min}$. To visualize mCherry, the tissue was incubated in goat $\alpha$-mouse gold-conjugated IgG (1:50; Aurion, catalog \#800.422) for $2 \mathrm{~h}$ at room temperature. Tissue was then washed with citrate buffer and silver-enhanced for $6.5 \mathrm{~min}$.

Following DAB and/or immunogold reactions, the tissue was fixed in $1 \%$ osmium tetroxide for $15 \mathrm{~min}$ in $0.1 \mathrm{M}$ phosphate buffer. Tissue was then washed and dehydrated through an ethanol series before being incubated in propylene oxide $(10 \mathrm{~min})$ and propylene oxide:EMBed (1:1 solution) overnight. Finally, the tissue was embedded in Aclar resin and placed in an oven at $60^{\circ} \mathrm{C}$ for $24 \mathrm{~h}$. Coronal sections measuring $700 \mathrm{~nm}$ were made using a Leica EM UC6 vibratome (Leica Microsystems). Some sections were mounted on glass slides and stained with toluidine blue in $0.5 \%$ sodium tetraborate to assist in region selection. Tissue from the suprapyramidal blade of the dentate gyrus was sectioned at $70 \mathrm{~nm}$ using an ultramicrotome (Leica Microsystems). Sections were placed on 200 square mesh copper/rhodium grids and counterstained with $5 \%$ uranyl acetate and Reynold's lead citrate. The MML was imaged at $11,000 \times$ on an FEI Technai $\mathrm{G}^{2} 12$ BioTWIN microscope (Thermo Fisher Scientific) at $80 \mathrm{kV}$. At least 10 representative images were selected in both control and TeNT-expressing conditions.

Experimental design and statistical analysis. Male and female mice were used for all experiments except developmental spine analysis, in which only males were used to provide more consistent results across animals. All data are reported as mean \pm SEM unless otherwise noted. For statistical analysis of electrophysiological datasets, the number of cells is reported in the text and was collected from 3-6 animals for each experiment. Statistical analysis was performed in Prism6 (GraphPad Software). Data were assumed to be normally distributed, in accordance with previous datasets in this circuit. Spine density data were analyzed using a two-way repeated-measures ANOVA (repeated measures: days postmitosis, lamina). Pooled data were analyzed using an ANOVA with Holm-Sidak post hoc analysis. Electrophysiology data were analyzed using two-tailed unpaired Student's $t$ tests. Linear regressions were performed using an extra-sum-of-squares $F$ test. Sample sizes were chosen to detect an effect size of $20 \%$, based on previous experiments, with a power of 0.8. Statistical significance was defined as $\alpha<0.05$, and was adjusted for post hoc comparisons (Holm-Sidak), as appropriate.

\section{Results \\ Adult-born granule cells receive preferential functional input from OML axons}

To examine the perforant path input onto newborn granule cells, we first compared electrical and optogenetic laminar-specific stimulation (Fig. 1A). Approximate targeting of the MPP or LPP was possible using a bipolar electrode as demonstrated by changes in the polarity of the field EPSP (fEPSP; Fig. 1B; Andersen et al., 1966). However, to specifically activate laminar-specific inputs to 
mature and newly integrating granule cells, we optogenetically labeled axons by injecting AAV9-CAG-ChR2-eGFP into either the medial or lateral entorhinal cortex, which provided precise labeling of either the MPP or LPP fibers in the molecular layer (Fig. 1C). To ensure that ChR2 expression was comparable across animals and slices, we used a range of stimulus intensities to determine a maximal evoked EPSC in mature cells from the MPP and LPP. Consistent with effective and laminar-specific ChR2 expression, the maximal EPSC amplitudes were the same for optical and electrical stimulation in the MPP (electrical stimulation: $105.0 \pm$ $17.4 \mathrm{pA}, n=7$ cells; optical stimulation: $123.0 \pm 24.7 \mathrm{pA}, n=19$ cells; unpaired $t$ test: 0.68 ) and the LPP (electrical stimulation:97.1 \pm $20.6 \mathrm{pA}, n=6$ cells; optical stimulation: $105.9 \pm 31.3 \mathrm{pA} ; n=16$ cells; unpaired $t$ test: 0.87 ) in mature granule cells.

As expected for mature cells, including mature granule cells generated from adult-born granule cells (Laplagne et al., 2006), the similar maximal amplitude of light-evoked EPSCs from the MPP or LPP indicates that mature cells receive robust and balanced excitatory input from both layers. In newly generated granule cells, inputs from both the medial and lateral entorhinal cortex can be detected at $>14 \mathrm{~d}$ postretroviral labeling (Kumamoto et al., 2012). However, surprisingly, in newly integrated neurons (identified by retroviral labeling at $21 \mathrm{~d}$ postmitosis), we found that the strength of LPP inputs was nearly 10 -fold larger than inputs from the MPP (MPP: $7.8 \pm 3.1 \mathrm{pA}, n=14$ cells; LPP: $72.2 \pm 15.2 \mathrm{pA}$, $n=18$ cells; Student's unpaired $t$ test: $t_{(30)}=3.68, p=0.0009$; Fig. $1 D, E)$. Despite the larger optically evoked EPSCs resulting from optical stimulation of the LPP, the band of fluorescent intensity of labeled axons was similar across the MML and the OML (Fig. 1C). Furthermore, because optically evoked responses in mature neurons were similar across laminae, it is unlikely that differences in innervation contribute to these results. Additionally, our slices were taken from the intermediate region of the longitudinal axis of the hippocampus, which has similar innervation patterns as the most dorsal regions (for review, see Strange et al., 2014). Recordings from mature and newly integrated neurons were obtained from the same animals, supporting the preferential functional innervation by LPP to newly integrated neurons (Fig. $1 D, E$ ).

The relatively reduced strength of MPP inputs in newly integrated granule cells could not be attributed to NMDA-only or "silent" synapses, as NMDA-evoked responses showed similar amplitude differences (MPP: $3.27 \pm 1.55 \mathrm{pA}, n=13$ cells; LPP: $37.68 \pm 10.38 \mathrm{pA}, n=13$ cells; Student's unpaired $t$ test: $t_{(24)}=3.28$; $p=0.0032)$. There also was no difference in the AMPA/NMDA ratio between lamina (MPP: $5.2 \pm 1.3, n=13$ cells; LPP: $3.66 \pm 0.58, n=$ 13 cells; Student's unpaired $t$ test: $t_{(24)}=1.04 ; p=0.31$; Fig. $1 F$ ). These results indicate that newly integrated neurons receive preferential, but not exclusive, functional input from the LPP.

\section{Synapse formation in newborn granule cells does not involve competitive elimination}

Given the differences in synaptic strength between LPP and MPP axons in newly integrated granule cells, we examined whether exuberant synapse formation occurs in the LPP, followed by competitive elimination and synaptic rebalancing, as is observed during early development (Goodman and Shatz, 1993; Katz and Shatz, 1996; Walsh and Lichtman, 2003). We labeled mitotically active neurons in 6-week-old male mice with a retroviral pRUBIGFP vector (Luikart et al., 2011), then examined spine density in granule cells in weekly intervals from 3 to 12 weeks postinjection in the MML and OML. Despite the functional difference in synapse strength in newly integrated granule cells, there was no difference in spine density between laminae at any time point (two-way repeated measure ANOVA: $F_{(1,2)}=0.195, p=0.7$ ). In grouped data from both laminae, the spine density increased from 3 to 4 weeks after injection ( 3 weeks: $0.94 \pm 0.07$ spines $/ \mu \mathrm{m}$, $n=35$ cells from 3 animals; 4 weeks: $1.52 \pm 0.03$ spines $/ \mu \mathrm{m}, n=$ 35 cells from 3 animals; Holm-Sidak post hoc comparison: $t_{(47)}=$ $4.5, p<0.001$; Fig. $2 A, B$ ), but remained constant from 4 to 12 weeks after injection (Holm-Sidak post hoc comparison: $p>0.05$ ). The spine density at 12 weeks was within the range of reported values for mature granule cells (Parent et al., 2016). There was a laminaindependent increase in the proportion of dendritic spines with filopodial-like morphology (compared with mushroom) in the MML ( 3 weeks: $13.3 \pm 1.3 \%$ of total spines, $n=14$ cells; 6 weeks: $23.21 \pm 2.6 \%$ of total spines, $n=16$ cells; Student's unpaired $t$ test: $t_{(28)}=3.29, p=0.0027$; Fig. $2 A, C$ ) and OML (3 weeks: $12.53 \pm 2.3 \%$ of total spines, $n=10$ cells; 6 weeks: $25.42 \pm 2.6 \%$ of total spines, $n=13$ cells; Student's unpaired $t$ test: $t_{(21)}=3.54$, $p=0.002$; Fig. $2 A, C)$.

In contrast to spine density and morphology, we did not detect a change in mEPSC frequency between 3 and 6 weeks after mitosis ( 3 weeks: $0.08 \pm 0.02 \mathrm{~Hz}, n=15$ cells; 6 weeks: $0.05 \pm$ $0.01 \mathrm{~Hz}, n=10$ cells; Student's unpaired $t$ test: $t_{(23)}=1.32, p=$ 0.20 ; Fig. $2 D, E)$. At 6 weeks after mitosis, there was a small and marginally significant decrease in the mESPC amplitude (3 weeks: $16.2 \pm 0.8 \mathrm{pA}, n=15$ cells; 6 weeks: $13.5 \pm 1.0 \mathrm{pA}, n=10$ cells, Student's unpaired $t$ test: $t_{(23)}=2.1, p=0.045$; Fig. $\left.2 D, F\right)$, perhaps consistent with the observed increase in filopodial spines (Holtmaat and Svoboda, 2009). Our data suggest that during the period of functional synaptic rebalancing in the perforant path, synapse formation by newly integrating granule cells does not follow a trajectory of a net overabundant spiny synapse formation followed by synaptic pruning.

\section{Chronic silencing of the MPP with TeNT}

To chronically silence axonal input in a laminar-specific manner, we virally expressed tetanus toxin light chain (TeNT), which cleaves the SNARE complex protein synaptobrevin-2, thereby preventing neurotransmitter release (Schiavo et al., 1992). We chose to use tetanus toxin because it has the advantage of completely silencing axons, with the disadvantage that the effects are irreversible. As the degree of silencing may influence effects on excitatory synapse formation (Bagley and Westbrook, 2012), we carefully validated our tetanus toxin vector in vitro and in vivo. First, we examined AMPA receptor currents in neurons in autaptic cultures (Tovar et al., 2009). In control cells, an unclamped action potential at the soma elicited a large-amplitude, NBQX-sensitive EPSC in all cells ( $n=7$ cells; Fig. $3 A, B)$. However, expression of TeNT by viral transfection completely abolished EPSCs (EPSC success rate: $0.22 \pm 0.2 \%, n=10$ cells, Student's unpaired $t$ test: $t_{(14)}=392.9 p<0.0001$; Fig. $\left.3 A, B\right)$.

To selectively silence MPP inputs in vivo, we injected an AAV9-TeNT-mCherry virus into the medial entorhinal cortex (Fig. 3C), resulting in robust laminar-specific expression of TeNT in MPP axons (Fig. 3C,D). TeNT expression was accompanied by a lamina-specific decrease in VGluT1 immunostaining ( $n=3$ animals), a marker of functional presynaptic terminals (Fig. 3D). Importantly, TeNT expression followed $\leq 6$ weeks in vivo did not elicit an inflammatory response ( $n=3$ animals; Fig. $3 E$ ), unlike the glial scarring that occurs following axotomy of MPP axons with subsequent degeneration of terminal axons (Perederiy et al., 2013). Immunogold electron micrographs of 
A

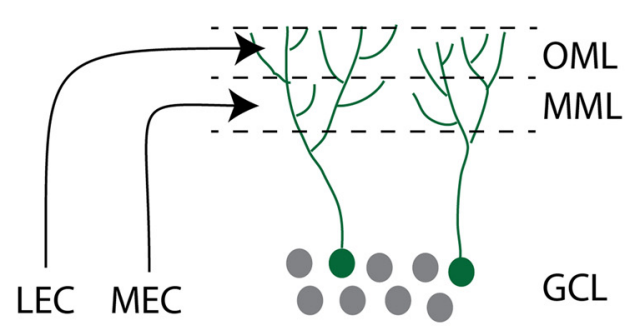

B

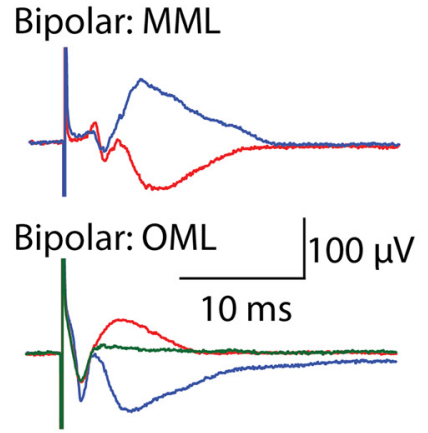

fEPSP: OML MML OML+NBQX

C
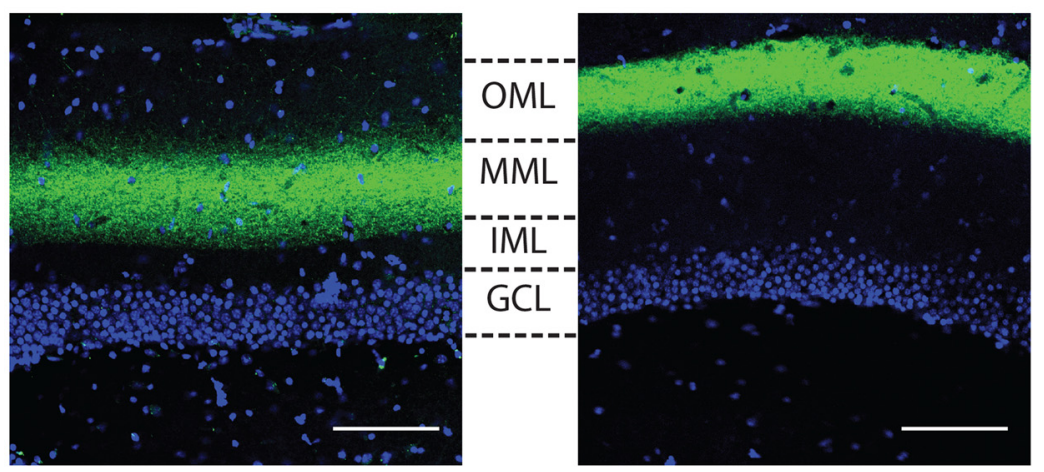

D
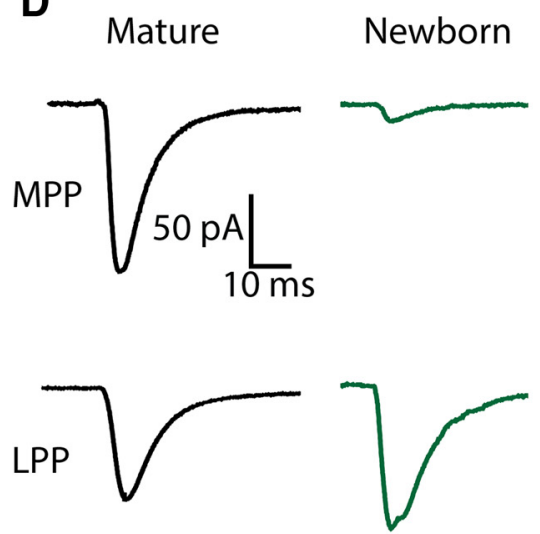

E

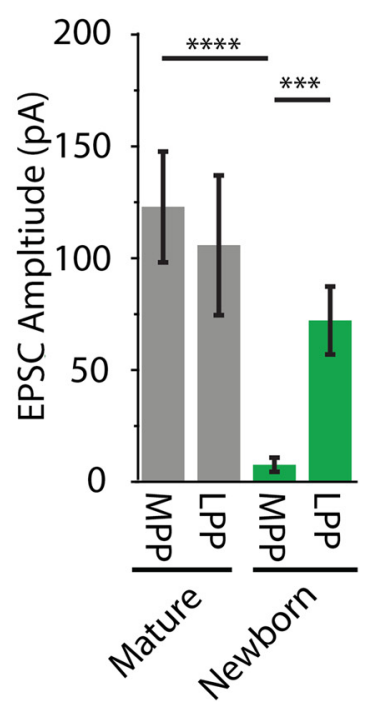

Figure 1. Laminar-specific electrical and optical stimulation. $A$, Circuit schematic demonstrating laminar-specific input from the medial entorhinal cortex (MEC) and the lateral entorhinal cortex (LEC). Within the molecular layer of the dentate gyrus, MEC axons reside in the MML, whereas lateral entorhinal cortex axons reside in the $0 \mathrm{ML}$. $\boldsymbol{B}$, Demonstration of laminar-specific input using fEPSP recordings. When the field recording electrode and bipolar electrode are within the same layer, a current sink is observed as a negative voltage deflection. A current source can be observed when the field electrode and bipolar electrode are in adjacent layers. Bath application of NBQX blocked the field response (green). C, Laminar-specific expression of ChR2 following viral injection into the medial entorhinal cortex (left) or lateral entorhinal cortex (right). Green, ChR2-GFP; blue, DAPI. Scale bar, 100 $\mu \mathrm{m} . \boldsymbol{D}$, Comparison of lamina-specific optogenetic stimulation in mature (black) and newborn cells (green). $\boldsymbol{E}$, Comparison of the strength of the maximal light-evoked EPSCs from each lamina in mature and newborn (postnatal day 21) granule cells. $\boldsymbol{F}$, Comparison of the AMPA/NMDA ratio in newly integrated granule cells following laminar-specific stimulation of the MPP or LPP. ${ }^{* * *} p<.001,{ }^{* * * *} p<.0001$.

TeNT-expressing axon terminals showed pronounced swelling as well as increased accumulation of small clear vesicles in presynaptic boutons, consistent with complete block of vesicular release (Fig. $3 F, G$ ). TeNT-expressing axon terminals were directly ap-
$\mathbf{F}$

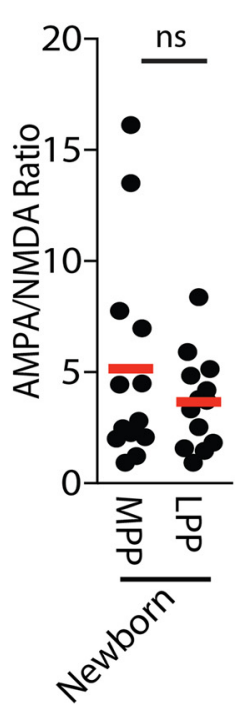

posed to dendritic spines, further suggesting that TeNT expression did not elicit axon degeneration.

To examine the efficiency of silencing of the MML, we recorded fEPSP responses to laminar-specific MPP electrical stimulation in control and TeNT-expressing slices. Consistent with our in vitro results, TeNT markedly reduced the maximal fEPSP slope (control: $0.67 \pm 0.07 \mu \mathrm{V} / \mathrm{ms}$, $n=6$ slices; TeNT: $0.26 \pm 0.02 \mu \mathrm{V} / \mathrm{ms}$, $n=5$ slices; Student's unpaired $t$ test: $t_{(9)}=5.4, p=0.0004$; Fig. $3 H$ ), as well as the input-output relationship between fiber volley amplitude and fEPSP slope (control: $0.52 \pm 0.003$; TeNT: $0.24 \pm 0.01$; extra-sum-of-squares $F$ test: $F_{(1,105)}=30.4$, $p<0.0001$; Fig. 3I). Importantly, there was no difference in the fiber volley amplitude with maximal stimulation (control: $-231.7 \pm 36.5 \mu \mathrm{V}, n=5$ slices; TeNT: $-197 \pm 29.8 \mu \mathrm{V}, n=5$ slices; Student's unpaired $t$ test: $t_{(8)}=0.74, p=$ 0.48 ), indicating that equal numbers of axons were stimulated in both conditions. The small residual fEPSP response observed in slices likely indicates that a few medial entorhinal cortex neurons had not been infected with TeNT.

\section{Silencing the MML impairs synapse formation with perforant path inputs} Although our results demonstrate that the MPP provides only weak functional input onto newly integrated granule cells, dendritic spines as well as weak synaptic responses (Kumamoto et al., 2012) are present, and thus these inputs could have an activity-dependent effect on circuit formation. To examine this possibility, we expressed ChR2-eGFP in LPP axons in conjunction with TeNT-mCherry expression in the MPP (MPP:TeNT; Fig. 4A). Interestingly, expression of TeNT in the MPP markedly reduced the amplitude of LPP responses in newly integrated granule cells (control: $72.2 \pm 15.2 \mathrm{pA}, n=18$ cells; MPP:TeNT: $8.7 \pm 3.7$ pA, $n=8$ cells; Student's unpaired $t$ test: $t_{(24)}=2.7, p=$ 0.011 ; Fig. $4 B, C)$, but not in mature granule cells (control: $105.9 \pm 31.3 \mathrm{pA}, n=16$ cells; MPP:TeNT: $125.7 \pm 23.24 \mathrm{pA}, n=$ 23 cells; Student's unpaired $t$ test: $t_{(37)}$ : $0.52, p=0.6$; Fig. $4 B, C)$. There was an associated increase in the paired pulse ratio (PPR) of LPP axons targeting newly integrated granule cells (control PPR: $0.9 \pm 0.08, n=18$ cells, MPP:TeNT PPR:

$1.8 \pm 0.3, n=8$ cells; Student's unpaired $t$ test: $t_{(24)}=4.3, p=0.0003$; Fig. $\left.4 B, D\right)$, which was not observed in mature granule cells (control PPR: $1.1 \pm 0.07, n=16$ cells; MPP:TeNT PPR: $1.4 \pm 0.2, n=23$ cells, Student's unpaired $t$ test: $t_{(37)}=1.38, p=0.17$; Fig. $\left.4 B, D\right)$. The increased PPR following 
A

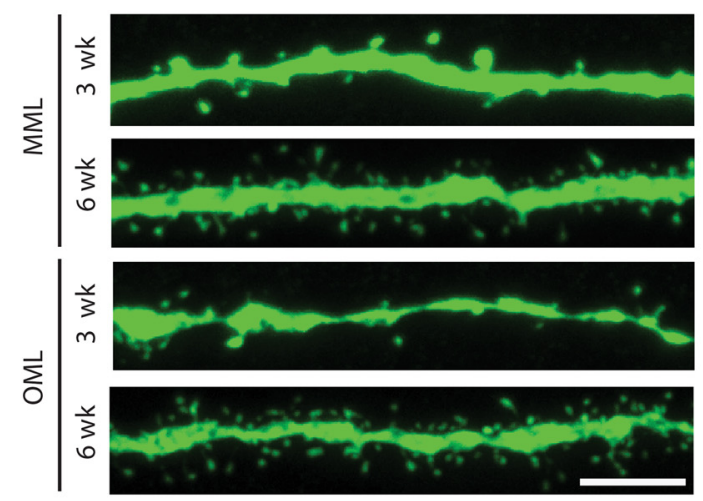

B

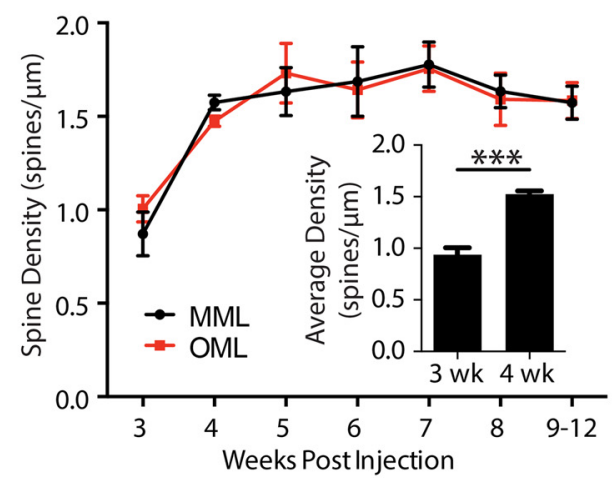

C

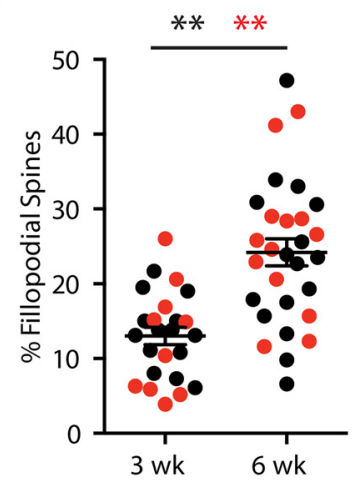

D

3 wpi granule cell
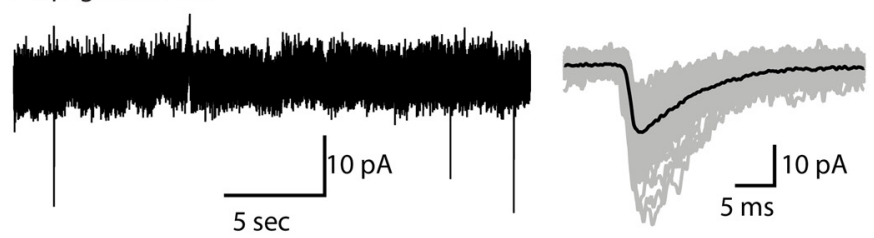

6 wpi granule cell

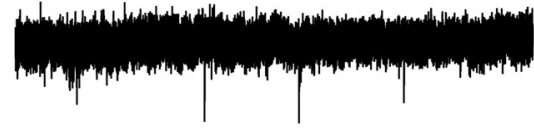

E

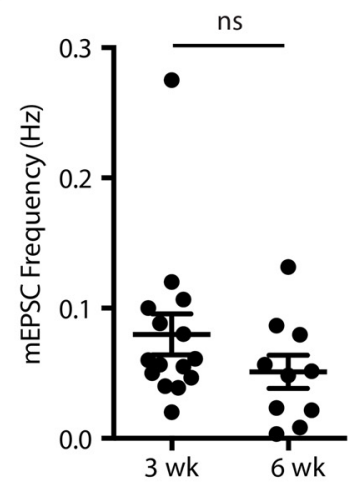

F

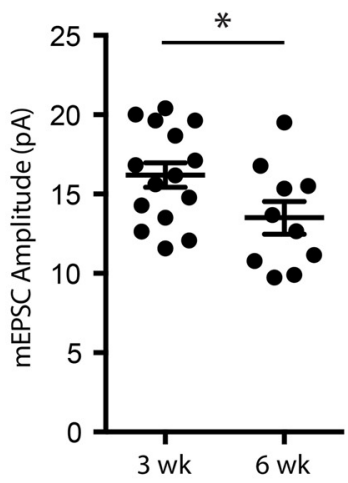

Figure 2. Synaptic maturation and development. A, Spine density measurements in MML (top) and OML (bottom) of 3-week-old and 6-week-old dentate granule cells. Scale bar, $5 \mu$ m. $B$, Developmental increase in spine density across cell development in MML (black) and OML (red). Inset, Average spine density across layers increases between 3 and 4 weeks after mitosis, then remains constant between 4 and 12 weeks. C, Developmental increase in the percentage of spines with filopodial morphology in both MML (black) and OML (red). $\boldsymbol{D}, \mathrm{mEPSC}$ recordings in the presence of $10 \mu \mathrm{m}$ SR95531 and $1 \mu \mathrm{m}$ TTX to isolate excitatory events. mEPSCs were recorded at 3 and 6 weeks after mitosis. $E$, There was no difference in the $m$ EPSC frequency at 3 and 6 weeks after mitosis. $F$, There was a significant decrease in mEPSC amplitude, suggesting weaker synaptic inputs at 6 weeks after mitosis. ${ }^{*} p<.05,{ }^{* *} p<.01,{ }^{* * *} p<.001$.

MPP:TeNT suggests that presynaptic mechanisms may contribute to the reduced amplitude.

Silencing of the MPP also greatly reduced the dendritic spine density of newly integrated granule cells in both the MML (control: $0.95 \pm 0.04$ spines $/ \mu \mathrm{m}, n=24$ cells from 4 animals; MPP: TeNT: $0.51 \pm 0.05$ spines $/ \mu \mathrm{m}, n=24$ cells from 4 animals; Student's unpaired $t$ test: $t_{(6)}=7.12, p=0.0004$; Fig. $\left.4 F, G\right)$ and OML (control: $0.93 \pm 0.03$ spines $/ \mu \mathrm{m}, n=24$ cells from 4 animals; MPP:TeNT: $0.54 \pm 0.02$ spines $/ \mu \mathrm{m}, n=24$ cells from 4 animals; Student's unpaired $t$ test: $t_{(6)}=11.01, p<0.0001$; Fig. $4 F, G)$. Together these results suggest that although the axons of the MPP make only a weak contribution to the synaptic activation of adult-born granule cells, intact synaptic release from MPP axons is required for proper synaptic integration and maturation.

\section{Discussion}

There is a general consensus that newborn neurons, once integrated into the dentate gyrus network, have a unique role in memory formation (Aimone et al., 2006; Saxe et al., 2006; Kee et al., 2007). Newborn neurons undergo stereotyped maturation, including early GABAergic depolarization without excitatory perforant input for several weeks (Ge et al., 2006) as their dendrites extend through the molecular layer (Zhao et al., 2006). Previous results have suggested that enhanced excitability and synaptic plasticity explain why such a minor population can have a major impact on circuit function (Schmidt-Hieber et al., 2004; Aimone et al., 2011). However, monosynaptic labeling studies using modified rabies virus (Vivar et al., 2012) suggest that newborn neurons in fact receive preferential functional input from the lateral entorhinal cortex, and only weak input from the medial entorhinal cortex.

\section{Preferential functional input onto newly integrated granule cells}

We observed striking differences in laminar-specific perforant path input to newly integrated granule cells. However, several studies have suggested that electrical stimulation of the MPP elicits EPSCs in newborn granule cells (Wang et al., 2000; Schmidt-Hieber et al., 2004; Ge et al., 2006, 2007; Mongiat et al., 2009). Although some studies have suggested that adult-born granule cells receive innervation from the MPP and LPP (Kumamoto et al., 2012), these studies used electrical stimulation of the molecular layer, which does not ensure laminar-specific stimulation. Also, the endpoint in these studies was the percentage of adult-born neurons contacted rather than the synaptic strength, which was assessed in our experiments. Furthermore, most of these experiments used indirect methods to determine the age of the granule cell (e.g., input resistance and soma location). Yet, the rapid changes in newly integrated granule cells after mitosis puts a premium on accurate determination of their age. In our experiments, we explicitly defined cell age with retroviral labeling and 
A

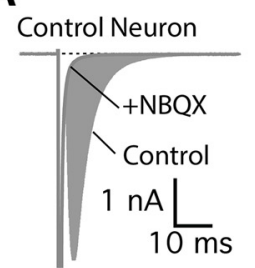

C

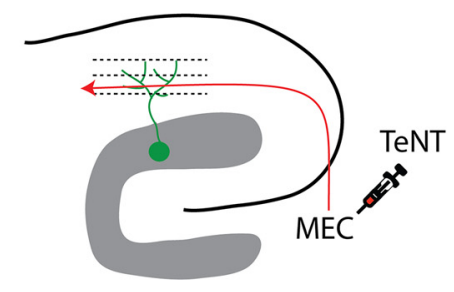

D

E

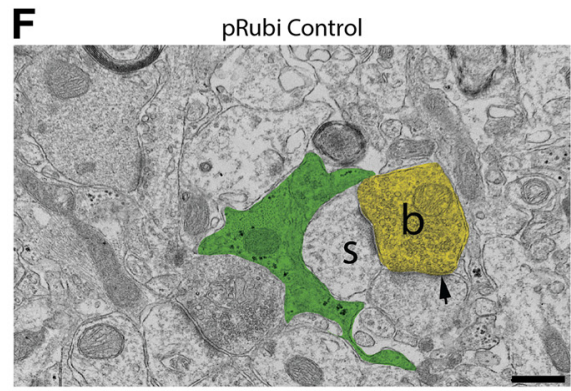

H

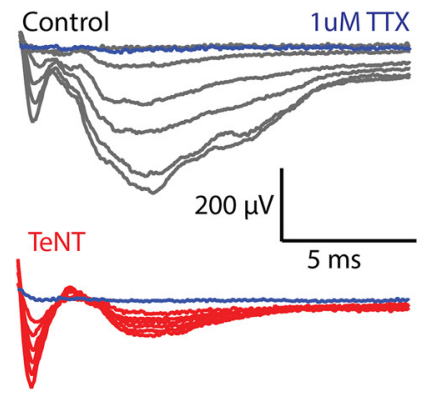

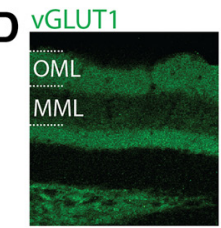
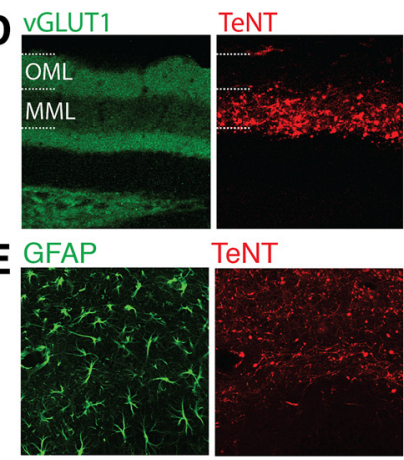

TeNT

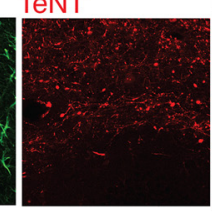

oTeNT-infected

G G TeNT Immunogold

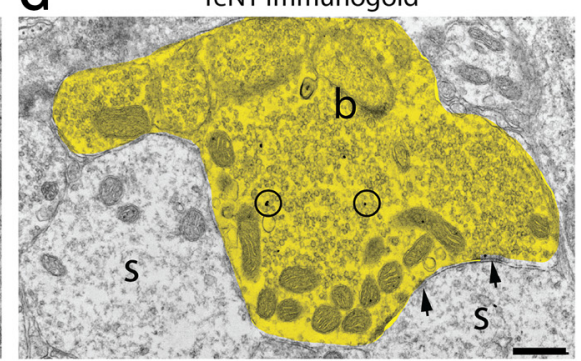

B

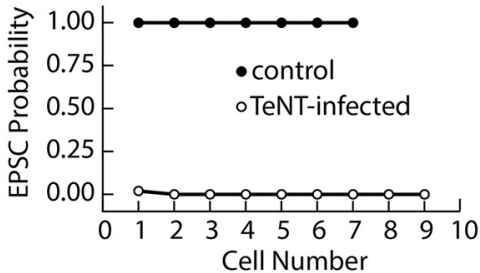

Merged

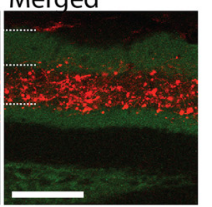

Merged

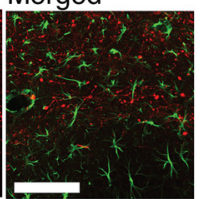

24. b

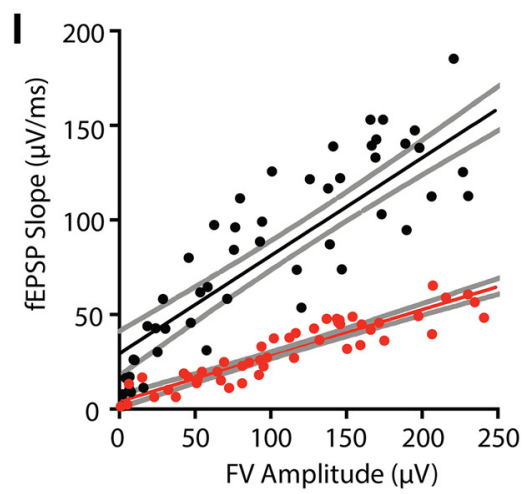

Figure 3. Silencing synaptic input with tetanus toxin expression. $A$, Comparison of synaptic responses in autaptically cultured neurons in control (left) and following tetanus toxin infection (TeNT). The shaded area indicates the AMPA-receptor EPSC. $\boldsymbol{B}$, Expression of TeNT abolishes synaptic responses in autaptically cultured neurons. C, Schematic of TeNT viral injection into the medial entorhinal cortex, which will functionally silence axons in the MML of the dentate gyrus. D, Expression of TeNT in the MML dramatically reduces the intensity of VGluT1 expression in the MML, indicating a disruption of presynaptic function. Scale bar, 100 $\mu \mathrm{m} . \boldsymbol{E}$, TeNT expression did not elicit astrogliosis. $\boldsymbol{F}, \boldsymbol{G}$, Electron micrographs from control $(\boldsymbol{F})$ and TeNT-overexpressing $(\boldsymbol{G})$ axons. TeNT expression results in axonal swelling and vesicle accumulation (b, axonal bouton; $s$, dendritic spine; arrowheads, synapses). $S$ cale bar, $500 \mathrm{~nm}$. $\boldsymbol{H}$, fEPSP recordings from the MML while electrically stimulating the MPP fibers. $\boldsymbol{I}$, fEPSP responses were significantly attenuated when TeNT was expressed in the MML, without changing fiber volley amplitudes.

verified laminar-specific stimulation with channelrhodopsin. This approach provided an unambiguous comparison of the strength of inputs from the medial and lateral entorhinal cortex in newly integrated granule cells. Although Deller et al. (1996) reported that inputs from the medial and lateral entorhinal cortex may not be perfectly anatomically separable, ChR2 labeling in our experiments was precisely laminar-specific.

Of note, episodic memory requires both spatial and nonspatial information, which are differentially encoded in the medial and lateral entorhinal cortex, respectively (Ferbinteanu et al., 1999; Hafting et al., 2005; Hargreaves et al., 2005; Yasuda and Mayford, 2006; Hunsaker et al., 2007; Deshmukh and Knierim, 2011; Yoganarasimha et al., 2011; Tsao et al., 2013; Van Cauter et al., 2013). Thus, the strict laminar organization in the molecular layer provides a framework in which distinct populations of granule cells or different regions of the dendritic tree may differentially affect circuit function (Magee, 2000; Dieni et al., 2013, 2016). The combination of preferential functional targeting of lateral entorhinal cortex inputs onto newly integrated granule cells thus complements their well-documented enhanced plasticity (Schmidt-Hieber et al., 2004; Abrous et al., 2005; Ge et al., 2007) in mediating distinct aspects of memory formation (Clelland et al., 2009; Sahay et al., 2011; Nakashiba et al., 2012; Tronel et al., 2012). This connectivity fits with a role of newly integrated neurons as novelty detectors for incoming contextual information, the essence of pattern separation (Deng et al., 2010; Aimone et al., 2011). Although the specific information carried by the LPP and MPP is likely more complex than a simple segregation of spatial and contextual input (Knierim et al., 2014), the lamination of the molecular layer suggests that the two inputs remain segregated along granule cell dendrites. One limitation of our results is that the data were obtained from the dorsal and intermediate regions of the hippocampus, which have similar connectivity. Thus, we cannot exclude the possibility that these results may be different in the most temporal tip of the hippocampus ("ventral"), which is known to have different connectivity (Strange et al., 2014).

At the synaptic level, the preferential functional input could not be attributed to an increase in "silent synapses" (Isaac et al., 1995; Carroll and Malenka, 2000; Ziv and Garner, 2001; Feldman, 2009), as there was no difference in the AMPA/ NMDA ratio between MPP and LPP inputs. Newborn granule cells in our experiments had robust AMPA-receptormediated EPSCs, despite reports that the first glutamatergic synapses on newborn granule cells are NMDA-only, silent synapses from hilar mossy cells onto the inner molecular layer (Chancey et al., 2013, 2014; Li et al., 2017). As NMDA receptors can detect low concentrations of glutamate, it may be difficult to separate NMDA-only silent synapses from spillover from nearby release sites. Perhaps surprisingly, the presence of the same density of spines in the OML and MML indicates that spine density and morphology are dissociated from functional synaptic strength in newly integrated granule cells. This difference also could not be attributed to differences in dendritic lengths within 
the MML and OML based on total dendritic length measurements of labeled granule cells (C. Chatzi and G.L. Westbrook, unpublished data). Although presynaptic axon terminals generally colocalize with postsynaptic spines, spine formation can be temporally distinct from functional synapse formation (Yuste and Bonhoeffer, 2004). In fact, following lesions of the perforant path, newly integrated granule cells continue to form dendritic spines despite the loss of presynaptic axon terminals (Perederiy et al., 2013; Sando et al., 2017). Other recent studies also suggest that dendritic spines can form in the absence of presynaptic terminals or glutamate release (Lu et al., 2013; Sando et al., 2017). Perhaps most important to our results, excitatory synapses may initially form on dendritic shafts particularly in relatively immature neurons (Crain et al., 1973; Miller and Peters, 1981; Mates and Lund, 1983; Yuste and Bonhoeffer, 2004; Fortin et al., 2014), which may explain why mEPSC frequency did not increase between 3 and 6 weeks after mitosis in our experiments, although evoked responses can increase over this time period (Ge et al., 2007; Marín-Burgin et al., 2012; Dieni et al., 2013, 2016). Unfortunately, there are as yet no straightforward methods to detect shaft synapses on newly integrated granule cells in intact tissue.

\section{The role of the MPP}

Our results indicate MPP inputs are necessary for normal synapse formation of all perforant path inputs on newly integrated granule cells. Adult-born granule cells in the hippocampus share many properties with immature neurons during development (Schmidt-Hieber et al., 2004; Abrous et al., 2005; Ge et al., 2007), but are unique because they integrate into a pre-existing circuit (Ge et al., 2007; Toni et al., 2007; Adlaf et al., 2017). The preferential functional targeting by the lateral entorhinal cortex might seem surprising given that as newborn cells mature, their dendrites first pass through the MML, which is occupied by axons innervating mature granule cells. On the other hand, this is the first perforant path glutamatergic input in these cells. Thus, even quite small events may provide a necessary signal for the subsequent development of spines and functional synapses in the OML. Chronic silencing of MPP inputs did not affect the lamination of incoming axons, but selectively reduced inputs onto newly integrated neurons. Silencing the MPP reduced spine density in both the MML and OML, although the reduction in synaptic strength was greater than the reduction in spine density, contrasting with patterns of homeostatic plasticity in other circuits (Davis, 2013). Furthermore, perforant path stimulation can elicit depolarizing GABAergic responses (Overstreet Wadiche et al., 2005; Ewell and Jones, 2010; Armstrong et al., 2011), which early in cell development can provide important trophic support (Ge et al., 2006; Chancey et al., 2013, 2014). Given the weak nature of this input, it may be that neurotrophic factors other than net neural activity contribute to the developmental role of MPP inputs (Huang and Reichardt, 2001; Cohen-Cory et al., 2010).

\section{Comparison to synapse formation during early development}

The existence of activity-dependent and competition-dependent synapse remodeling is well mapped in the immature brain as neural circuits develop (Goodman and Shatz, 1993; Katz and Shatz, 1996; Walsh and Lichtman, 2003). In many developing circuits, an overabundance of weak synapses is later pruned in a competitiondependent manner, resulting in the retention of strong synaptic inputs (Bear, 1995; Knudsen, 2004; Majewska and Sur, 2006; Bhatt et al., 2009; Feldman, 2009), thereby shaping the mature, functional circuit (LeVay et al., 1980; Walsh and Lichtman, 2003; Datwani et al., 2009). Synapse pruning and redistribution occur during critical periods of development, when incoming patterns of activity strongly influence circuit remodeling (Malenka and Bear, 2004; Holtmaat and Svoboda, 2009; Caroni et al., 2014). However, in the adult brain, such circuit plasticity is more limited (Tagawa et al., 2005; Sato and Stryker, 2008), suggesting that the pattern of initial synapse formation and subsequent remodeling/refinement in adult-born cells may be distinct. Indeed, we did not see a distinct period of synaptic overabundance as newly integrated cells reached maturity. Rather synaptic "competition" for newly integrating neurons must reflect a homeostatic rebalancing of functional inputs across the molecular 
layer, which must occur over a relatively narrow time window, as newborn granule cells are functionally indistinguishable from mature granule cells by 8 weeks after mitosis (van Praag et al., 2002; Ambrogini et al., 2004; Overstreet et al., 2004; Laplagne et al., 2006; Overstreet-Wadiche et al., 2006; Zhao et al., 2006; Brunner et al., 2014). Such competition need not only occur between synapses on the same cell and can occur between mature and newly integrated neurons (Toni et al., 2007; McAvoy et al., 2016; Adlaf et al., 2017). Importantly, remodeling in the adult environment is relevant to both neurogenic niches and repair after neural injury (Lindvall and Kokaia, 2006; Lepousez et al., 2015).

\section{References}

Abrous DN, Koehl M, Le Moal M (2005) Adult neurogenesis: from precursors to network and physiology. Physiol Rev 85:523-569. CrossRef Medline

Adlaf EW, Vaden RJ, Niver AJ, Manuel AF, Onyilo VC, Araujo MT, Dieni CV, Vo HT, King GD, Wadiche JI, Overstreet-Wadiche L (2017) Adult-born neurons modify excitatory synaptic transmission to existing neurons. Elife 6.pii:e19886. CrossRef Medline

Aimone JB, Wiles J, Gage FH (2006) Potential role for adult neurogenesis in the encoding of time in new memories. Nat Neurosci 9:723-727. CrossRef Medline

Aimone JB, Deng W, Gage FH (2011) Resolving new memories: a critical look at the dentate gyrus, adult neurogenesis, and pattern separation. Neuron 70:589-596. CrossRef Medline

Ambrogini P, Lattanzi D, Ciuffoli S, Agostini D, Bertini L, Stocchi V, Santi S, Cuppini R (2004) Morpho-functional characterization of neuronal cells at different stages of maturation in granule cell layer of adult rat dentate gyrus. Brain Res 1017:21-31. CrossRef Medline

Andersen P, Holmqvist B, Voorhoeve PE (1966) Entorhinal activation of dentate granule cells. Acta Physiol Scand 66:448-460. CrossRef Medline

Armstrong C, Szabadics J, Tamás G, Soltesz I (2011) Neurogliaform cells in the molecular layer of the dentate gyrus as feed-forward $\gamma$-aminobutyric acidergic modulators of entorhinal-hippocampal interplay. J Comp Neurol 519:1476-1491. CrossRef Medline

Bagley EE, Westbrook GL (2012) Short-term field stimulation mimics synaptic maturation of hippocampal synapses. J Physiol 590:1641-1654. CrossRef Medline

Bear MF (1995) Mechanism for a sliding synaptic modification threshold. Neuron 15:1-4. CrossRef Medline

Bhatt DH, Zhang S, Gan WB (2009) Dendritic spine dynamics. Annu Rev Physiol 71:261-282. CrossRef Medline

Boss BD, Peterson GM, Cowan WM (1985) On the number of neurons in the dentate gyrus of the rat. Brain Res 338:144-150. CrossRef Medline

Brunner J, Neubrandt M, Van-Weert S, Andrási T, Kleine Borgmann FB, Jessberger S, Szabadics J (2014) Adult-born granule cells mature through two functionally distinct states. Elife 3:e03104. CrossRef Medline

Caroni P, Chowdhury A, Lahr M (2014) Synapse rearrangements upon learning: from divergent-sparse connectivity to dedicated sub-circuits. Trends Neurosci 37:604-614. CrossRef Medline

Carroll RC, Malenka RC (2000) Delivering the goods to synapses. Nat Neurosci 3:1064-1066. CrossRef Medline

Chancey JH, Adlaf EW, Sapp MC, Pugh PC, Wadiche JI, Overstreet-Wadiche LS (2013) GABA depolarization is required for experience-dependent synapse unsilencing in adult-born neurons. J Neurosci 33:6614-6622. CrossRef Medline

Chancey JH, Poulsen DJ, Wadiche JI, Overstreet-Wadiche L (2014) Hilary mossy cells provide the first glutamatergic synapses on adult-born dentate granule cells. J Neurosci 34:2349-2354. CrossRef Medline

Clelland CD, Choi M, Romberg C, Clemenson GD Jr, Fragniere A, Tyers P, Jessberger S, Saksida LM, Barker RA, Gage FH, Bussey TJ (2009) A functional role for adult hippocampal neurogenesis in spatial pattern separation. Science 325:210-213. CrossRef Medline

Cohen-Cory S, Kidane AH, Shirkey NJ, Marshak S (2010) Brain-derived neurotrophic factor and the development of structural neuronal connectivity. Dev Neurobiol 70:271-288. CrossRef Medline

Crain B, Cotman C, Taylor D, Lynch G (1973) A quantitative electron microscopic study of synaptogenesis in the dentate gyrus of the rat. Brain Res 63:195-204. CrossRef Medline

Datwani A, McConnell MJ, Kanold PO, Micheva KD, Busse B, Shamloo M, Smith SJ, Shatz CJ (2009) Classical MHCI molecules regulate retino- geniculate refinement and limit ocular dominance plasticity. Neuron 64: 463-470. CrossRef Medline

Davis GW (2013) Homeostatic signaling and the stabilization of neural function. Neuron 80:718-728. CrossRef Medline

Deller T, Martinez A, Nitsch R, Frotscher M (1996) A novel entorhinal projection to the rat dentate gyrus: direct innervation of proximal dendrites and cell bodies of granule cells and GABAergic neurons. J Neurosci 16: 3322-3333. CrossRef

Deng W, Aimone JB, Gage FH (2010) New neurons and new memories: how does adult hippocampal neurogenesis affect learning and memory? Nat Rev Neurosci 11:339-350. CrossRef Medline

Deshmukh SS, Knierim JJ (2011) Representation of non-spatial and spatial information in the lateral entorhinal cortex. Front Behav Neurosci 5:69. CrossRef Medline

Dieni CV, Nietz AK, Panichi R, Wadiche JI, Overstreet-Wadiche L (2013) Distinct determinants of sparse activation during granule cell maturation. J Neurosci 33:19131-19142. CrossRef Medline

Dieni CV, Panichi R, Aimone JB, Kuo CT, Wadiche JI, Overstreet-Wadiche L (2016) Low excitatory innervation balances high intrinsic excitability of immature dentate neurons. Nat Commun 7:11313. CrossRef Medline

Dolorfo CL, Amaral DG (1998) Entorhinal cortex of the rat: topographic organization of the cells of origin of the perforant path projection to the dentate gyrus. J Comp Neurol 398:25-48. CrossRef Medline

Ewell LA, Jones MV (2010) Frequency-tuned distribution of inhibition in the dentate gyrus. J Neurosci 30:12597-12607. CrossRef Medline

Feldman DE (2009) Synaptic mechanisms for plasticity in neocortex. Annu Rev Neurosci 32:33-55. CrossRef Medline

Ferbinteanu J, Holsinger RM, McDonald RJ (1999) Lesions of the medial or lateral perforant path have different effects on hippocampal contributions to place learning and on fear conditioning to context. Behav Brain Res 101:65-84. CrossRef Medline

Fortin DA, Tillo SE, Yang G, Rah JC, Melander JB, Bai S, Soler-Cedeño O, Qin M, Zemelman BV, Guo C, Mao T, Zhong H (2014) Live imaging of endogenous PSD-95 using ENABLED: a conditional strategy to fluorescently label endogenous proteins. J Neurosci 34:16698-16712. CrossRef Medline

Ge S, Goh EL, Sailor KA, Kitabatake Y, Ming GL, Song H (2006) GABA regulates synaptic integration of newly generated neurons in the adult brain. Nature 439:589-593. CrossRef Medline

Ge S, Yang CH, Hsu KS, Ming GL, Song H (2007) A critical period for enhanced synaptic plasticity in newly generated neurons of the adult brain. Neuron 54:559-566. CrossRef Medline

Goodman CS, Shatz CJ (1993) Developmental mechanisms that generate precise patterns of neuronal connectivity. Cell 72 Suppl:77-98. Medline

Hafting T, Fyhn M, Molden S, Moser MB, Moser EI (2005) Microstructure of a spatial map in the entorhinal cortex. Nature 436:801-806. CrossRef Medline

Hargreaves EL, Rao G, Lee I, Knierim JJ (2005) Major dissociation between medial and lateral entorhinal input to dorsal hippocampus. Science 308: 1792-1794. CrossRef Medline

Harris KM, Jensen FE, Tsao B (1992) Three-dimensional structure of dendritic spines and synapses in rat hippocampus (CA1) at postnatal day 15 and adult ages: implications for the maturation of synaptic physiology and long-term potentiation [published erratum appears in J Neurosci 1992 Aug; 12 (8): following table of contents]. J Neurosci 12:2685-2705. CrossRef Medline

Holtmaat A, Svoboda K (2009) Experience-dependent structural synaptic plasticity in the mammalian brain. Nat Rev Neurosci 10:647-658. CrossRef Medline

Huang EJ, Reichardt LF (2001) Neurotrophins: roles in neuronal development and function. Annu Rev Neurosci 24:677-736. CrossRef Medline

Hunsaker MR, Mooy GG, Swift JS, Kesner RP (2007) Dissociations of the medial and lateral perforant path projections into dorsal DG, CA3, and CA1 for spatial and nonspatial (visual object) information processing. Behav Neurosci 121:742-750. CrossRef Medline

Isaac JT, Nicoll RA, Malenka RC (1995) Evidence for silent synapses: implications for the expression of LTP. Neuron 15:427-434. CrossRef Medline

Katz LC, Shatz CJ (1996) Synaptic activity and the construction of cortical circuits. Science 274:1133-1138. CrossRef Medline

Kee N, Teixeira CM, Wang AH, Frankland PW (2007) Preferential incorporation of adult-generated granule cells into spatial memory networks in the dentate gyrus. Nat Neurosci 10:355-362. CrossRef Medline 
Knierim JJ, Neunuebel JP, Deshmukh SS (2014) Functional correlates of the lateral and medial entorhinal cortex: objects, path integration and localglobal reference frames. Philos Trans R Soc Lond B Biol Sci 369:20130369. CrossRef Medline

Knudsen EI (2004) Sensitive periods in the development of the brain and behavior. J Cogn Neurosci 16:1412-1425. CrossRef Medline

Kumamoto N, Gu Y, Wang J, Janoschka S, Takemaru K, Levine J, Ge S (2012) A role for primary cilia in glutamatergic synaptic integration of adultborn neurons. Nat Neurosci 15:399-405, S1. CrossRef Medline

Laplagne DA, Espósito MS, Piatti VC, Morgenstern NA, Zhao C, van Praag H, Gage FH, Schinder AF (2006) Functional convergence of neurons generated in the developing and adult hippocampus. PLoS Biol 4:e409. CrossRef Medline

Lepousez G, Nissant A, Lledo PM (2015) Adult neurogenesis and the future of the rejuvenating brain circuits. Neuron 86:387-401. CrossRef Medline

LeVay S, Wiesel TN, Hubel DH (1980) The development of ocular dominance columns in normal and visually deprived monkeys. J Comp Neurol 191:1-51. CrossRef Medline

Li L, Sultan S, Heigele S, Schmidt-Salzmann C, Toni N, Bischofberger J (2017) Silent synapses generate sparse and orthogonal action potential firing in adult-born hippocampal granule cells. eLife 6.pii::e23612. CrossRef Medline

Lindvall O, Kokaia Z (2006) Stem cells for the treatment of neurological disorders. Nature 441:1094-1096. CrossRef Medline

Lu W, Bushong EA, Shih TP, Ellisman MH, Nicoll RA (2013) The cellautonomous role of excitatory synaptic transmission in the regulation of neuronal structure and function. Neuron 78:433-439. CrossRef Medline

Luikart BW, Schnell E, Washburn EK, Bensen AL, Tovar KR, Westbrook GL (2011) Pten knockdown in vivo increases excitatory drive onto dentate granule cells. J Neurosci 31:4345-4354. CrossRef Medline

Magee JC (2000) Dendritic integration of excitatory synaptic input. Nat Rev Neurosci 1:181-190. CrossRef Medline

Majewska AK, Sur M (2006) Plasticity and specificity of cortical processing networks. Trends Neurosci 29:323-329. CrossRef Medline

Malenka RC, Bear MF (2004) LTP and LTD: an embarrassment of riches. Neuron 44:5-21. CrossRef Medline

Marín-Burgin A, Mongiat LA, Pardi MB, Schinder AF (2012) Unique processing during a period of high excitation/inhibition balance in adultborn neurons. Science 335:1238-1242. CrossRef Medline

Mates SL, Lund JS (1983) Spine formation and maturation of type 1 synapses on spiny stellate neurons in primate visual cortex. J Comp Neurol 221:91-97. CrossRef Medline

McAvoy KM, Scobie KN, Berger S, Russo C, Guo N, Decharatanachart P, Vega-Ramirez H, Miake-Lye S, Whalen M, Nelson M, Bergami M, Bartsch D, Hen R, Berninger B, Sahay A (2016) Modulating neuronal competition dynamics in the dentate gyrus to rejuvenate aging memory circuits. Neuron 91:1356-1373. CrossRef Medline

Miller M, Peters A (1981) Maturation of rat visual cortex. II. A combined Golgi-electron microscope study of pyramidal neurons. J Comp Neurol 203:555-573. CrossRef Medline

Ming GL, Song H (2011) Adult neurogenesis in the mammalian brain: significant answers and significant questions. Neuron 70:687-702. CrossRef Medline

Mongiat LA, Espósito MS, Lombardi G, Schinder AF (2009) Reliable activation of immature neurons in the adult hippocampus. PLoS One 4:e5320. CrossRef Medline

Nakashiba T, Cushman JD, Pelkey KA, Renaudineau S, Buhl DL, McHugh TJ, Rodriguez Barrera V, Chittajallu R, Iwamoto KS, McBain CJ, Fanselow MS, Tonegawa S (2012) Young dentate granule cells mediate pattern separation, whereas old granule cells facilitate pattern completion. Cell 149:188-201. CrossRef Medline

Ohara S, Sato S, Tsutsui K, Witter MP, Iijima T (2013) Organization of multisynaptic inputs to the dorsal and ventral dentate gyrus: retrograde trans-synaptic tracing with rabies virus vector in the rat. PLoS One 8:e78928. CrossRef Medline

Overstreet LS, Hentges ST, Bumaschny VF, de Souza FS, Smart JL, Santangelo AM, Low MJ, Westbrook GL, Rubinstein M (2004) A transgenic marker for newly born granule cells in dentate gyrus. J Neurosci 24:3251-3259. CrossRef Medline

Overstreet Wadiche L, Bromberg DA, Bensen AL, Westbrook GL (2005) GABAergic signaling to newborn neurons in dentate gyrus. J Neurophysiol 94:4528-4532. CrossRef Medline
Overstreet-Wadiche LS, Westbrook GL (2006) Functional maturation of adultgenerated granule cells. Hippocampus 16:208-215. CrossRef Medline

Overstreet-Wadiche LS, Bensen AL, Westbrook GL (2006) Delayed development of adult-generated granule cells in dentate gyrus. J Neurosci 26: 2326-2334. CrossRef Medline

Parent AS, Pinson A, Woods N, Chatzi C, Vaaga CE, Bensen A, Gérard A, Thome JP, Bourguignon JP, Westbrook GL (2016) Early exposure to aroclor 1254 in vivo disrupts the functional synaptic development of newborn hippocampal granule cells. Eur J Neurosci 44:3001-3010. CrossRef Medline

Perederiy JV, Luikart BW, Washburn EK, Schnell E, Westbrook GL (2013) Neural injury alters proliferation and integration of adult-generated neurons in the dentate gyrus. J Neurosci 33:4754-4767. CrossRef Medline

Rolls ET, Treves A, Rolls ET (1998) Neural networks and brain function. Oxford: Oxford UP.

Sahay A, Scobie KN, Hill AS, O'Carroll CM, Kheirbek MA, Burghardt NS, Fenton AA, Dranovsky A, Hen R (2011) Increasing adult hippocampal neurogenesis is sufficient to improve pattern separation. Nature 472:466470. CrossRef Medline

Sando R, Bushong E, Zhu Y, Huang M, Considine C, Phan S, Ju S, Uytiepo M, Ellisman M, Maximov A (2017) Assembly of excitatory synapses in the absence of glutamatergic neurotransmission. Neuron 94:312-321.e3. CrossRef Medline

Sato M, Stryker MP (2008) Distinctive features of adult ocular dominance plasticity. J Neurosci 28:10278-10286. CrossRef Medline

Saxe MD, Battaglia F, Wang JW, Malleret G, David DJ, Monckton JE, Garcia AD, Sofroniew MV, Kandel ER, Santarelli L, Hen R, Drew MR (2006) Ablation of hippocampal neurogenesis impairs contextual fear conditioning and synaptic plasticity in the dentate gyrus. Proc Natl Acad Sci U S A 103:17501-17506. CrossRef Medline

Schiavo G, Benfenati F, Poulain B, Rossetto O, Polverino de Laureto P, DasGupta BR, Montecucco C (1992) Tetanus and botulinum-B neurotoxins block neurotransmitter release by proteolytic cleavage of synaptobrevin. Nature 359:832-835. CrossRef Medline

Schmidt-Hieber C, Jonas P, Bischofberger J (2004) Enhanced synaptic plasticity in newly generated granule cells of the adult hippocampus. Nature 429:184-187. CrossRef Medline

Strange BA, Witter MP, Lein ES, Moser EI (2014) Functional organization of the hippocampal longitudinal axis. Nat Rev Neurosci 15:655-669. CrossRef Medline

Tagawa Y, Kanold PO, Majdan M, Shatz CJ (2005) Multiple periods of functional ocular dominance plasticity in mouse visual cortex. Nat Neurosci 8:380-388. CrossRef Medline

Toni N, Teng EM, Bushong EA, Aimone JB, Zhao C, Consiglio A, van Praag H, Martone ME, Ellisman MH, Gage FH (2007) Synapse formation on neurons born in the adult hippocampus. Nat Neurosci 10:727-734. CrossRef Medline

Toni N, Laplagne DA, Zhao C, Lombardi G, Ribak CE, Gage FH, Schinder AF (2008) Neurons born in the adult dentate gyrus form functional synapses with target cells. Nat Neurosci 11:901-907. CrossRef Medline

Tovar KR, Maher BJ, Westbrook GL (2009) Direct actions of carbenoxolone on synaptic transmission and neuronal membrane properties. J Neurophysiol 102:974-978. CrossRef Medline

Tronel S, Belnoue L, Grosjean N, Revest JM, Piazza PV, Koehl M, Abrous DN (2012) Adult-born neurons are necessary for extended contextual discrimination. Hippocampus 22:292-298. CrossRef Medline

Tsao A, Moser MB, Moser EI (2013) Traces of experience in the lateral entorhinal cortex. Curr Biol 23:399-405. CrossRef Medline

Van Cauter T, Camon J, Alvernhe A, Elduayen C, Sargolini F, Save E (2013) Distinct roles of medial and lateral entorhinal cortex in spatial cognition. Cereb Cortex 23:451-459. CrossRef Medline

van Groen T, Miettinen P, Kadish I (2003) The entorhinal cortex of the mouse: organization of the projection to the hippocampal formation. Hippocampus 13:133-149. CrossRef Medline

van Praag H, Schinder AF, Christie BR, Toni N, Palmer TD, Gage FH (2002) Functional neurogenesis in the adult hippocampus. Nature 415:10301034. CrossRef Medline

Vivar C, Potter MC, Choi J, Lee JY, Stringer TP, Callaway EM, Gage FH, Suh $\mathrm{H}$, van Praag H (2012) Monosynaptic inputs to new neurons in the dentate gyrus. Nat Commun 3:1107. CrossRef Medline 
Walsh MK, Lichtman JW (2003) In vivo time-lapse imaging of synaptic takeover associated with naturally occurring synapse elimination. Neuron 37:67-73. CrossRef Medline

Wang S, Scott BW, Wojtowicz JM (2000) Heterogenous properties of dentate granule neurons in the adult rat. J Neurobiol 42:248-257. CrossRef Medline

Witter MP (2007) The perforant path: projections from the entorhinal cortex to the dentate gyrus. Prog Brain Res 163:43-61. CrossRef Medline

Yasuda M, Mayford MR (2006) CaMKII activation in the entorhinal cortex disrupts previously encoded spatial memory. Neuron 50:309-318. CrossRef Medline
Yoganarasimha D, Rao G, Knierim JJ (2011) Lateral entorhinal neurons are not spatially selective in cue-rich environments. Hippocampus 21:13631374. CrossRef Medline

Yuste R, Bonhoeffer T (2004) Genesis of dendritic spines: insights from ultrastructural and imaging studies. Nat Rev Neurosci 5:24-34. CrossRef Medline

Zhao C, Teng EM, Summers RG Jr, Ming GL, Gage FH (2006) Distinct morphological stages of dentate granule neuron maturation in the adult mouse hippocampus. J Neurosci 26:3-11. CrossRef Medline

Ziv NE, Garner CC (2001) Principles of glutamatergic synapse formation: seeing the forest for the trees. Curr Opin Neurobiol 11:536-543. CrossRef Medline 